\title{
THE INFLUENCE OF THE EUROPEAN SEMESTER ON EMPLOYMENT POLICY IN CROATIA, $2013-2016$
}

\author{
Mario Munta \\ Faculty of Political Science \\ University of Zagreb \\ E-mail:munta.mario@phd.ceu.edu
}

DOI: 10.20901/an.14.09

Original scientific article

Accepted: December 2017

\begin{abstract}
This paper analyzes the effects of the European Semester, EU's framework for socio-economic policy coordination, on change of Croatian employment policy. The case of Croatia is used to illustrate in what manner, under which conditions and to what extent the European Semester architecture actually influences Croatian employment policies. The focus is on two policy items: the Youth Guarantee and the retirement age provision. The findings on the Youth Guarantee lend crucial support to the expectation that intensified monitoring and reporting obligations will contribute to domestic policy change. Drawing on interview data, the author identifies administrative pressure and low familiarity with the European Commission's modus operandi within the European Semester as two crucial elements of influence. On the other hand, Croatia repeatedly neglected EU's recommendation to step up the harmonization of female and male retirement age. Reasons for low European Semester impact on this issue can be found in a number of constraining conditions that were at play: coalition politics, the stickiness of the policy issue, opposite policy beliefs and a highly uncertain political situation. These factors acted as deterrents from policy change despite potential EU sanctions down the pike.
\end{abstract}

Keywords European Semester, Europeanization, employment policy, Croatia, Youth Guarantee, retirement

\section{Introduction}

Many ambitious projects have attempted to grasp the European Union's influence on employment policies in Member States in the past (Barcevičius et al. 2014; Graziano et al. 2011, Büchs 2007; Zeitlin and Pochet 2005; Heidenreich and Zeitlin 2009). Embedded in the Europeanization literature and new modes of governance research, these scholars have taken on the task of exploring causal mechanisms that stand between the EU as a cause and the policy changes that it might have triggered. However, the financial and eco- nomic crisis led to large-scale changes in the EU's socio-economic governance. The European Semester was created as a yearly cycle of policy surveillance which integrates a number of fiscal, macroeconomic, employment and social governance mechanisms. Knowing how the European Semester influences domestic policy change is still a research desideratum (Verdun and Zeitlin 2017). This paper takes the case of Croatia and poses the questions as to in what way, under which conditions and to what extent the European Semester architecture influences Croatian employment policies. 
European economic governance after the crisis has been troubled by tough choices - should the new governance framework tighten the monitoring and enforcement capacity of supranational actors, or is the EU to step up and intensify alternative, soft methods of coordinating economic and social (incl. employment) policies? I start from the assumption that this tension has been reflected in the institutional development of economic governance post-crisis. In exploring interlinkages of governance procedures on the one hand and intensified multilateral surveillance, monitoring and reporting obligations on the other, I focus on two policy items - the Youth Guarantee and the retirement age provision. The findings on the Youth Guarantee lend crucial support to the expectations which intensified monitoring and reporting obligations contribute to domestic policy innovation. Drawing on interview data, I identify administrative pressure and low familiarity with the European Commission's ${ }^{1}$ modus operan$d i$ within the European Semester as two crucial elements in the chain of influence. On the other hand, Croatia repeatedly neglected EU's recommendation to step up the harmonization of female and male retirement age. Reasons can be found in coalition politics, the stickiness of the policy issue, opposite policy beliefs, as well as in a highly uncertain political situation, all of which acted as deterrents from policy change despite potential sanctioning down the road.

The paper continues as follows. The first section describes the procedural functioning of the European Semester, followed by a review of the newest innovations within employment coordination at EU level. Section 3 introduces the analytical framework including the

1 Hereafter, the terms "European Commission" and "Commission" will be used interchangeably. causal pathways, conditions and aspects of policy change that can be expected to result from European Semester sources of influence. Section 4 looks at the European Semester in play and analyzes the Youth Guarantee and retirement age items in Croatia. The final section is the conclusion to the paper.

\section{The European Semester: Streamlining Policy Coordination in the EU}

Facing a severe financial crisis that grew into a full-fledged economic recession and sovereign debt crisis, European leaders were anxious to cushion the negative effects of the crisis: firstly, on the Economic and Monetary Union (EMU), and, secondly, on the EU's overall economy (Verdun 2015: 223-224). Among other crisis-management tools, the EU passed a series of acts, such as the Six-pack and the Two-pack regulation which increased the Commission's authority over budgetary and macroeconomic monitoring (Savage and Verdun 2016: 101). These reforms amplified the punitive aspect of economic governance, both in the Stability and Growth Pact and in the new Macroeconomic Imbalance Procedure (Martínez-Yáñez 2016: 529), although these sanctioning mechanisms are yet to be applied against Member States in practice. One of key governance innovations introduced in 2010 as part of the broader Six-pack was the European Semester $^{2}$ - an annual cycle of socio-economic surveillance which brings together and streamlines existing coordination efforts, i.e. the Europe 2020 agenda, the Stability and Growth Pact, the Macroeconomic Imbalance Procedure and the Euro Plus Pact. In effect, it monitors the implementation of (fiscal) rules

\footnotetext{
2 In this paper, the term "European Semester" and "Semester" will be used interchangeably.
} 
and guidelines of all coordination mechanisms, some of which rely more on soft coordination (Euro Plus Pact and Europe 2020), whereas others combine soft and hard (law) tools (the Stability and Growth Pact and the Macroeconomic Imbalance Procedure) (Bekker and Klosse 2014: 8). The European Semester starts by outlining the following year's economic priorities (Annual Growth Survey). The Commission then analyzes fiscal and socio-economic developments in Member States, including progress towards area-specific guidelines and recommendations for the previous year (Country Report). Country Reports are followed by National Reform Programs submitted by governments. These describe efforts made or to be made in order to meet EU-targets, rules and recommendations. The European Commission assesses reforms and drafts country-specific recommendations (CSRs) addressed to each Member States. The remaining six months are reserved for national implementation. This paper tries to understand what sort of a capacity the European semester architecture has so as to influence domestic employment policies. Before I move to the analytical framework, the following section explains how employment coordination fits within the European Semester.

\section{EU Employment Coordination in the European Semester}

Employment coordination traditionally operates within the context of a "new mode of governance" termed the Open Method of Coordination (OMC), which can be contrasted to what Scott and Trubek (2002) call 'the classic Community method' - the usual decision-making process in the EU. The OMC is often termed "soft law" (Mosher and Trubek 2003) because of the non-binding character of policy guidelines or recommen- dations that are issued. Member States cannot be forced by law to translate EUagreed employment goals into domestic action. Although EU institutions have the right to define common goals and targets, they have no competencies to directly regulate the coordinated policy. Furthermore, the OMC is characterized by the absence of sanctioning mechanisms. Finally, policy coordination operates within the context of soft policy instruments such as guidelines, targets, indicators (benchmarking), mutual learning, peer reviewing and other non-intrusive mechanisms. These are intended to spell out common goals, scrutinize national policy trends and action, and facilitate voluntary transfer of policies through deliberation and learning from successful examples. It is believed that soft coordination can build consensus and enhance convergence between countries in areas in which Member States resist deeper integration (Heritier 2003).

In the framework of the European Semester, new employment guidelines and objectives are defined every five years, with Member States receiving employment-related recommendations on a yearly basis. However, some interesting trends were noted since the start of the Semester. Despite fears following the initial iterations of the Semester that employment and social policies would be subdued to the objectives of fiscal consolidation and macroeconomic stability, a gradual process of "socialization" of the Semester was distinguished (Zeitlin 2016: 1084). According to some commentators, this meant a re-installment of the social and employment dimension in the Semester - in the form of an expanded social scope of recommendations (Gomez Urquijo 2017), the enhanced role of the Employment Committee in extending mutual learning opportunities and peer reviews and new monitoring tools developed in coopera- 
tion with the Social Protection Committee (Zeitlin and Vanhercke 2014). However, others claim that the tightening of the economic governance procedures has meant more intrusions of fiscal and macroeconomic objectives into welfare state policies than before the reform period (De la Porte and Heins 2015: 3-4). In practical terms, this trend is reflected in those country-specific recommendations legally based in the more stringent procedures of the Stability and Growth Pact and the Macroeconomic Imbalance Procedure, but nevertheless increasingly include suggestions for interventions in the social and employment field. Since the two coordination processes rely on strict enforcement and monitoring, they effectively diminish Member States' "room for maneuver" in the labor market policy, social policy proper, healthcare or pension systems (11). As I will demonstrate in the coming section, these two trends have significant implications on the capacity of the European Semester to influence the national (employment) policy arena.

\section{A Framework for Analyzing European Semester Influence}

The main interest of this paper is to investigate how (by means of which mechanisms) and under which conditions the European Semester manages to influence domestic policy changes in the field of employment policies. In doing so, this paper sides with Gerven et al. (2014: 509) in their opinion that a thorough understanding of Europeanization processes necessitates a deeper inquiry into the mechanisms of influence, rather than an illusory attempt to simply establish relationships of direct impact. By building on the two trends in socio-economic governance from the previous section, I conceptualize the European Semester governance features as sources of influence on domestic policy change. Empirical analysis has thus far been scarce; however, some studies found either limited impact of country-specific recommendations (De la Porte and Heins 2015: 13; Hallerberg et al. 2012) or a poor implementation record of CSRs (Deroose and Griesse 2014; Zuleeg 2015). Others noted an increased politicization of employment recommendations as they became a reference point to stakeholders and the media (Louvaris Fasois 2016), or the strategic usage of specific targets ("cherry-picking") in the European Semester framework (Eihmanis 2017).

\section{Mechanisms}

The starting point of the causal analysis is the presence of a misfit between EU targets/goals/guidelines/indicators and domestic policy. This paper assumes that a more pronounced policy misfit leads to an increased pressure to adapt ${ }^{3}$ (Börzel and Risse 2000). I extract four principle mechanisms from the literature (see: Moumoutzis and Zartaloudis 2016; Barcevičius 2014; De la Porte and

3 As critics rightly point out, the goodness of fit is by no means a necessary condition for policy change (Mastenbroek and Kaeding 2016). This is especially true in the sphere of soft law such as employment policy. However, this paper holds that any impulses from the EU-level that would point to bad goodness of fit can become sources of domestic political usage, depending on the preferences and belief systems of domestic actors. A large-scale misfit may thus empower two fronts : (1) policy-makers who exploit the opportunity to point to the misfit in order to advance a pre-existing agenda or preference and hence to legitimize an action; (2) societal actors, if influential enough to stir public debate and, since inclined towards change, may make strategic reference to the high misfit to build prochange coalitions. Also, if the government perceives the large misfit as an indicator of policy failure, it may search for solutions on the EU level and engage in drawing lessons from other Member States. In that case, the presence of policy entrepreneurs will be crucial in initiating change (Sabatier 2007). 
Pochet 2012) which may form the causal pathway between cause and effect. The first mechanism relates to external incentives in the Semester - either positive incentives or sanctions to which Member States react. These can be rule-based criteria (i.e. SGP rules) backed by sanctions triggered in absence of policy change. External constrains can also take the form of naming-and-shaming practices which rely on the publicity of European semester outputs. Policy-makers calculate potential reputational or electoral losses in the course of non-compliance with proposed policy changes. Positive incentives (awards), such as access to funding, are attached to substantive conditions of the European Semester. The relationship between the European Semester and the ESF has been boosted via the 2013 funding regulations reform. On the one hand, Member States must comply with pre-specified employment objectives, ex-ante conditionalities and target expenditures relevant to the CSRs in order to become eligible for funding. On the other hand, however, the European Commission may require reprogramming of funds to support a CSR and the objectives of the SGP/MIP, or propose suspensions in case of no action, which leads to a further hardening of CSRs. As a consequence, the use of ESF money is less flexible and more centrally controlled than ever before (Armstrong 2012: 294).

A second mechanism (leverage effect) describes a frequent phenomenon where governments and other actors selectively cherry-pick from the plethora of EU initiatives or ideas and use them as levers to boost their influence in policy-making processes, in building coalitions or legitimizing their action (Woll and Jacquot 2008). Peer pressure (third mechanism) can mean either (1) persuasion by peers (other Member States or EU officials) to change domestic policies in order to pursue collective EU goals, whereby na- tional policymakers become convinced about the right courses of action, or (2) extensive and frequent pressure on domestic public administration to report back on progress or state of affairs in a certain policy matter, and in-depth EU scrutiny of the domestic policy field. The European Semester encourages enhanced interaction between European Commission administration and national administrations through intensified monitoring and feedback exercises related to planned policy actions. The multi-level governance arrangements created therein are interactive and formally non-hierarchical; however, Commission officials aim to ensure that national administrators adhere to both the overall EU-level objectives of the European Semester and to country-specific measures and targets. Administrative pressure thus relates to instances in which civil servants of different Commission DGs engage in frequent remote and on-theground surveillance of national policy progress and request repeated in-depth reporting on planned and executed policy measures by competent authorities. These measures are to aim at meeting pre-defined policy goals in the European Semester framework. The European Commission seeks to push and steer domestic reform processes in that direction. Member States must now report on the implementation of CSRs, provide detailed intelligence on the content of undertaken policy measures and comply with deadlines for responding to requests (Bekker 2013: 5). Intense monitoring and reporting activities are hence expected to increase the pressure to comply with EU requests (Maggetti and Gilardi 2014: 1295).

A final mechanism, mutual learning in the European Semester, pertains to all forms of collective learning ${ }^{4}$ that

\footnotetext{
4 See Dunlop and Radaelli (2013) for varieties of collective learning.
} 
occur in EU fora such as the Employment Committee (EMCO) or the Employment, Social Policy, Health and Consumer Affairs Council (EPSCO). Mutual learning is generated when actors alter their understanding of policy goals, means and problems in a process of learning. However, policy-makers do not consider changing policies due to suggestions by their peers, but as the result of reflection and autonomous conviction about the appropriateness to address certain policy problems. The literature has noted that the importance of the EMCO in enhancing European Semester's influence increased by way of its intensified monitoring capacity, frequency and type of peer review activities it organizes (both ex-post and ex-ante), the potential for mutual learning it creates and substantive influence on the content of country-specific recommendations it is said to have (see: Zeitlin and Vanhercke 2014).

\section{Intervening Conditions}

This paper distinguishes between domestic and EU-level factors (conditions) that either facilitate or inhibit the causal pathway. Domestically, Member States belonging to the group of Eurozone countries face tighter monitoring and can be subjected to financial sanctions under the preventive and corrective arms of the SGP and MIP which makes "compliance" more likely (Bekker 2015: 4). If both popular and elite (government) sentiment towards the EU and the European Commission is positive, Member States will be more open to (even unpopular) initiatives from Brussels. In countries with coalition governments, pivotal coalition parties might act as veto players if a policy change would be to the detriment of their constituency ${ }^{5}$. Unlike Cacciatore et al.
(2016: 1191), I expect national administrations to be more likely to accept input from Brussels the less accustomed they are to EU practices and procedures, simply because they have not learnt how to "play the Brussels game" yet in novel circumstances. They might therefore be more permissive in engaging with EU requests uncritically. Finally, it is worth noticing Deroose and Griesse's (2014: 6) finding that states tend not to implement recommendations neither in election years, nor in the aftermath of elections. I would add to this that popular EU incentives will be used regardless of election proximity whenever they can be used as a lever in the election campaign. On the European level, I also side with deliberative intergovernmentalism in arguing that the effectiveness of multilateral surveillance and mutual learning depends on the ability of key policy-makers to "grasp technical knowledge" during EU-level deliberation, and the closeness and frequency of their interactions with senior civil servants (Puetter 2012: 165). In relation to this matter, it has been argued by Puetter (2014) that informal settings and working methods conducive to consensus-building and deliberation become crucial for successful policy implementation. The conditions-expected directions of influence (positive or negative) are summarized in Table 1.

\section{Outcomes}

When it comes to the forms of policy change resulting from European Semester activity, I borrow from the OMC literature (Heidenreich 2009; Barcevičius et al. 2014) in distinguishing between procedural and substantive shifts. Procedural changes refer to changes in national governance and policymaking in a broad

when proposed policy changes deviate from electoral promises, or when they have predominantly negative distributive consequences on key constituencies. 
Table 1. Summary of the analytical framework

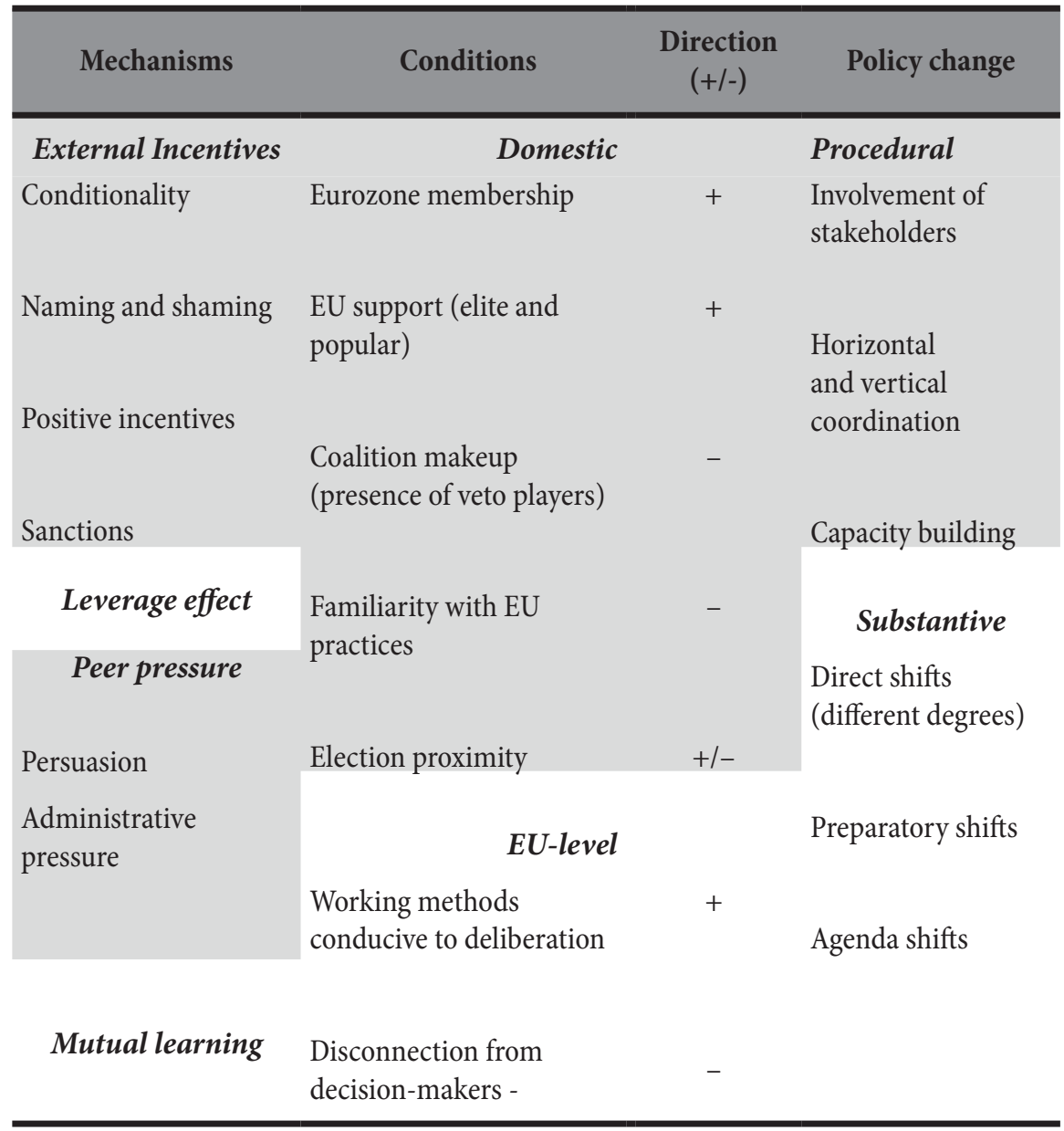

Source: Author's own compilation.

sense, including (1) the establi shing of horizontal and vertical coordination in European Semester issues that cut across sectors, be it in the form of inter-ministerial coordination, multi-level cooperation (i.e. technical support from EU) or between branches of government; (2) the inclusion of non-state actors (i.e. social partners, NGOs) in decision-making on European Semester matters, either through newly-created bodies or existing ones, and (3) building administrative capacities (human, organizational resources) or establishing new institutions. Substantive changes can include direct policy chan- ge $^{6}$ changes in the importance of policy problems (preparatory shifts), ${ }^{7}$ or take the form of new agendas set.

\footnotetext{
6 Meaning, i.e. change in laws and regulations occurring on three levels (Hall 1993): (1) change in the setting of policy instruments - i.e. lowering the duration of unemployment benefits from 12 to 6 months; (2) change of existing policy instruments or introduction of new ones - i.e. providing job counseling; (3) transformative change of both policy goals and instruments - i.e. shift from passive to active approach by linking benefit rights to job-search obligations.

7 When a government initiates discussions, starts using EU concepts in debates, frames
} 
Table 2. List of expert interviews

\begin{tabular}{|c|c|c|c|}
\hline Code & Current/former institutional affiliation & Date & Place \\
\hline A1 & Ministry of Labor and Pension System & $14 / 11 / 2016$ & Zagreb, HR \\
\hline A2 & Ministry of Labor and Pension System & $14 / 11 / 2016$ & Zagreb, HR \\
\hline A3 & Ministry of Labor and Pension System & $07 / 03 / 2017$ & Zagreb, HR \\
\hline B1 & Croatian Public Employment Service & $11 / 11 / 2016$ & HR \\
\hline B2 & Croatian Public Employment Service & $08 / 03 / 2017$ & Zagreb, HR \\
\hline $\mathrm{C} 1$ & $\begin{array}{l}\text { Representation of the European Commission to } \\
\text { Croatia }\end{array}$ & $11 / 06 / 2016$ & Zagreb, HR \\
\hline D1 & Croatian Parliament, European Affairs Committee & $15 / 03 / 2017$ & Zagreb, HR \\
\hline E1 & European Commission, DG ECFIN & $18 / 07 / 2017$ & Brussels, BE \\
\hline
\end{tabular}

\section{Methodological note}

In this paper I look at the case of Croatia to test the analytical framework. Having joined the EU only in 2013, Croatia is a particularly interesting case for to the study of the EU's causal influence. The European Semester processes are highly politicized in this country, and a great number of employment and labor market reforms ${ }^{8}$ have been initiated in the meanwhile. On the other hand, Croatia has only recently exited the "sticks-andcarrots" phase of pre-entry negotiations, hence might be a good case to see whether it has either continued "complying" or started experiencing integration fatigue. Lastly, Croatia has been one of Member States with the highest problem load on the labor market - recording above average unemployment rates, youth un-

policies in accordance with EU initiatives, opens discussions/consultations for a policy, establishes working groups, creates a task force or commission, prepares a bill, passes a strategic document or action plan.

8 Including the following: introduction of a large Youth traineeship program, change in the Labor Code, modernisation of the Public Employment Service, establishment of a new job counselling center(CISOK), and the increase of retirement age. employment rates, inactivity rates, longterm unemployment rates and early retirement rates. I will focus on the Youth Guarantee and the retirement age regulations as two prominent policy items. Croatia made substantial progress in implementing the Youth Guarantee and limited progress on retirement age (see section 4.1). This makes the former a most-likely case, and the later a least-likely case (Rohlfing 2016). It is so because, from an ex-ante point of view, there is less confidence of finding evidence that the European Semester influenced a policy item in which little or no policy change was present. Methodologically it is worthwhile studying such cases as they may reveal the conditions which prevent or reduce the influence of the European Semester.

I make use of qualitative data analysis to draw conclusions. Eight (semi-structured) expert interviews have been conducted in Croatia in the period July 2016 - July 2017. The interview coding, institutional affiliations and interview periods are shown in Table 2. The sampling strategy of this specific paper was tailored to cover the insights of senior civil servants involved in the day-today activities on the European Semester. 
These interviews represent the primary sources for the empirical part of this paper, supplemented by secondary sources, ranging from Country Reports, National Reform Programs, Country-specific Recommendations to strategic policy documents, laws, regulations and evaluation studies. On occasion, I draw from newspaper articles and TV news.

\section{The European Semester in Action}

Five years into deep recession, Croatia entered the EU on 1 July 2013 as one of EU's countries which were hit the hardest by the economic crisis. The labor market was in bad shape due to a combination of large external shocks (excessive imbalances, deficit and debt skyrocketing) and domestic structural weaknesses (Brkic 2015: 19). The Croatian youth in particular were facing high unemployment rates, prolonged job search and inactivity periods resulting from the highly cyclical nature of youth unemployment (Bejakovic et al. 2015: 1). They saw their labor market position deteriorate substantially during the crisis years (Vuksic 2014). Fiscal, macroeconomic and employment outlooks were rather gloomy as Croatia prepared to participate in the 2013 European Semester cycle for the first time, although on a voluntary basis. That year, Croatia submitted its first informal, and hence preparatory reform program within the European Semester cycle entitled "2013 Economic Programme of Croatia". The programme outlined Croatia's policy responses to the priorities set in the 2013 Annual Growth Survey (AGS) and regarding the Europe 2020 targets. The European Commission then published a working document (CSWD) with the "Assessment of the 2013 economic programme for Croatia". No formal country-specific recommendations were made that year; nevertheless, the Eco- nomic and Financial Committee issued a Council conclusion on Croatia, highlighting a number of labor market and employment-related issues to be tackled. ${ }^{9}$ Soon thereafter, Croatia was put under the scrutiny of the Stability and Growth Pact and the Macroeconomic Imbalance Procedure. Having breached the $3 \%$ deficit and $60 \%$ debt rule, Croatia entered the excessive deficit procedure (EDP) on 21 January 2014. Likewise, the March 2014 In-depth Review accompanying the Country Report concluded that Croatia was experiencing macroeconomic imbalances due to poor competitiveness, weak export position, meager growth potential and high external liabilities. Findings of these two procedures would eventually feed into the country-specific recommendations in the European Semester. The following section gives a general overview of Croatian employment issues raised in the European Semester setting (2013-2016), the procedural changes that were triggered by the European Semester, and the capacity of EU fora (primarily EMCO), as seen from the perspective of Croatian members of EMCO, to foster peer pressure and mutual learning.

\section{Limited policy progress and low potential for policy transfer}

European Semester matters can be coordinated in multiple ways, both horizontally and vertically. As one of the direct effects of entering the Semester, the Croatian Government created an inter-ministerial working group under the cap of the Ministry of Regional Development and EU Funds. The main bulk of work consisted in coordinating the procedural obligations within the

\footnotetext{
9 Including the rigidity of the Croatian labor market; the position of youth; hiring and firing costs; disincentives to work; effectiveness of active labor market measures; and the matching of labor demand and supply (Council 2013).
} 
yearly cycle - the drafting of the National Reform Program being the central task. Besides the ministerial level meetings, subgroups were set up, i.e. the Working Group on employment policy, which would then analyze EU targets, recommendations and guidelines on a technical level, establish indicators of success and monitor progress towards goals. ${ }^{10}$ With the start of the mandate of the technocratic government of Tihomir Orešković, the central Working Group was relocated to the Prime Minister's Office, which was evaluated positively by European Commission officials. It signaled the increase of relevance of the European Semester and cast aside potential accusations of catering to specific interests of the Ministry of Regional Development. ${ }^{11}$ Raising the profile of the European Semester continued with the new right-wing government led by Andrej Plenković. His office stepped up efforts to make Croatia's involvement in the Semester more transparent by bringing the meat of the Semester closer to citizens on the official government website. ${ }^{12}$ In general, officials from the Ministry of Labor and Pension System have the impression that the European Semester, acting as a monitoring device, "somehow contributed to the understanding that policies cannot be created as one wishes them to be, but that one is to carefully think things through". ${ }^{13}$ However, when it comes to issues of vertical coordination between ministers/ decision-makers and experts participating in the EMCO meetings, the view is less optimistic. One EMCO member noted that, at times, there was uncertainty regarding the official positions of the government: "There were situations where I did not know the Croatian po-

\footnotetext{
10 Interviewee A3.

11 Interviewee $\mathrm{C} 1$.

12 See: https://vlada.gov.hr/europski-semestar/19453

13 Interviewee A2.
}

sition and the position of the competent Ministry...I could have relied on my professional opinion, but EMCO members are not there to do that". ${ }^{14}$

Two-way communication was also poor: direct contacts with the minister did not exist, which points to a certain disconnection from decision-makers. Interviewees were uncertain about the impact of their briefing activities: "Look, minister's assistants always show interest...They are informed, we brief them, talk to them and give our comments. Now, what happens afterwards, I do not know". ${ }^{15}$ In sum, communication is one-sided, and can be understood as providing information to higher levels. A final comment is due regarding the relationship between branches of government. Despite the fact that Regulation 1466/2011 calls for a closer involvement of national parliaments and relevant stakeholders in activities of the cycle, the Croatian context is unfavorable to both. The European Affairs Committee of the Croatian Parliament participates on a symbolic level -they are sometimes informed about the content of the National Reform Program and Convergence Plan before it is passed, but at other occasions this is so only afterwards. Either way, there are no internal procedures in place to outline the cooperation mode between the two branches in Semester matters. Furthermore, members of the Committee do not participate in the substantive drafting of Semester documents. ${ }^{16}$ On the other hand, social partners are also excluded from any substantive involvement in the drafting of the National Reform Programme and failure to promote social dialogue and nurture the partnership principle in formulating employment policies has been identi-

\footnotetext{
14 Interviewee B1.

15 Interviewee A1.

16 Interviewee D1.
} 
fied as one of the biggest flaws in the policy-making process. ${ }^{17}$

There is less empirical evidence in the Croatian case to support the view that the EMCO setting creates space for deliberation and consensus-building, which ought to facilitate mutual learning experiences. EMCO meetings bring together people from employment ministries and public employment services, Commission staff and members of permanent representations to discuss national employment policies and give their input to Commission's proposals of country-specific recommendations. EMCO members generally agree on the usefulness of peer review activities; however, they are often more of a formality than a true opportunity to learn something new. As one member put it: "In thematic reviews, everyone is trying to sell their own ideas. The Commission and the discussant country send in their questions in advance... Other colleagues seem to be bored, although good practice examples can be heard". ${ }^{18}$ Another member adds: "...other member states do not participate...mostly those presenting after you do not listen. Still, there are always class leaders who have something to ask". ${ }^{19}$ On the other hand, the meetings are a good opportunity to discuss national policy measures more deeply in person with Commission staff, which can influence what the end version of the Country Report looks like. ${ }^{20}$ When country-specific recommendations are discussed, the Commission has the rigid attitude, and Member States tend to stick together and act supportively towards each other. ${ }^{21}$ When representatives were eager to water down or change certain formulations, the Com-

17 Interviewee A3.

18 Interviewee B2.

19 Interviewee A1.

20 Interviewee A1.

21 Interviewees B2 and A1. mission seemed more prone to stick to initial formulations, whereas the Member State would lobby for support or offer support to other countries' complaints in exchange for support on their items. ${ }^{22}$ These moments in which certain items with policy implications were discussed, either during the votes on CSRs or in peer reviews, were described as being "not entirely comfortable" and "tense". ${ }^{23}$ What can be concluded from this short overview is that EMCO meetings served less the purpose of influencing policy formulations, but more the purpose of becoming informed about what lies ahead or what is expected from the country in the periods to come. The findings of this paper provide support to a previous testimony by Coman and Ponjaert (2016) who argued that EMCO members' interventions stand little chance of success against the Commission's formulations on CSRs.

Turning to European Union's CRSs in the field of employment policies, former government members emphasize the relative weakness of the Semester's capacity to bring something new to the table in terms of policy innovations in active labor market policies or other employment measures. ${ }^{24}$ On the one hand, there was little room for novelties, but on the other, Croatia had been under a great deal of influence from European employment initiatives before the country joined the EU as well. ${ }^{25}$ Table 3 summarizes all employment recommendations to the Croatian National Reform Program issued by the Council in the period 2014-2016. It lists the topics of items raised, signals whether the CSRs were included in other governance procedures ${ }^{26}$, and indicates

\footnotetext{
22 Interviewee B1.

23 Interviewee $\mathrm{B} 1$.

24 Interviewee A3.

25 Interviewee A3.

26 Which can be said by looking at the formulation in the explanatory text to the CSRs.
} 
the degree of implementation of these, as evaluated by Commission staff in the Country Report.

In 2014, three of the eight CSRs referred to employment policies, and all of them were presented as part of the Macroeconomic Imbalance Procedure. Most notably, the Commission had complaints about the slow harmonization of male and female retirement ages, poor alignment of wages with productivity trends, the issue of sufficient administrative capacities of the Croatian Employment Service to perform activation measures, as well as weak outreach to non-registered youth as part of the Youth Guarantee scheme. The recommendations were quite detailed, contained deadlines for implementation and in some cases suggested policy means that should be used (i.e. increasing the effectiveness of the social benefit system by creating a one-stop-shop). In the 2015 Country Report, substantial or full progress was noted with regard to the activation of non-registered youth (NEETs) and the implementation of the second phase of the Labor Code reform. In comparison to 2014, CSRs were much more succinct in 2015:no deadlines were attached to measures, but the recommendations still suggested the course of action to be taken. Croatia was asked to tackle early retirement by raising penalties for early exits from the labor market. Also, the recommendations once again raised the problem of the wage-setting mechanism which should follow productivity gains and macroeconomic trends. All CSRs were again part of the Macroeconomic Imbalance Procedure, but progress in all areas was considered limited. Finally, in 2016, the sticky issue of statutory retirement age figured prominently in the recommendations, as well as the issues of unadjusted wages in the public sector and unconsolidated social benefit schemes. Despite including deadlines, the 2017 Country Report signaled limited progress. Throughout all three cycles, the CSRs had an economic tone in that they asked for fiscal sustainability of the pension system or productivity adjustments in wage-setting. The fact that all CSRs without exception were linked to MIP, but, curiously, no impact on the compliance record was felt, calls the effectiveness of the European Semester into question. I turn to the examples of the Youth Guarantee (substantial progress) and the retirement age dispute (limited progress) to see which causal pathways and conditions make the European Semester relevant and which do not.

\section{The Youth Guarantee}

Youth unemployment became a hot topic on the EU agenda only after the outbreak of the 2008 economic crisis (Chabanet 2014: 489). In April 2013, the Council passed a recommendation on establishing a Youth Guarantee (2013/C 120/01) foreseen under the Youth Employment Package scheme a year earlier. The policy idea was simple, namely to urge Member States to offer youth aged 15-24 a good-quality employment, training or education opportunity within 4 months of becoming unemployed or exiting the formal education system. Although the concept was not entirely innovative since similar recommendations were made a decade earlier within the 1998 and 2003 Employment Guidelines (Copeland and ter Haar 2015: 19), the Youth Guarantee quickly gained traction in the media. Besides the central tenet of the Youth Guarantee to offer employment, training or education within 4 months of unemployment, the policy design of the Youth Guarantee put special emphasis on reintegration into the labor market of vulnerable youth - non-registered youth that are not 
employed, not in education and not in training (so called NEETs).

As far as governance tools are concerned, the Youth Guarantee was promoted through multiple channels - a special Council recommendation, individual CSRs within the Semester, exchange of good practices in the mutual learning program, progress reports, as one of the investment priorities of one of the thematic objective in the European Social Fund regulation for 2014-2020, and as an ex-ante condition (establishing a Youth Guarantee strategic framework). Financial support for the measure was complemented by the Youth Employment Initiative. In governance terms, the Youth Guarantee was embedded in the MIP procedure (both as an indicator and as a CSR), the Europe 2020 strategy, and the European Social Fund. The interlinkages and complementarities of these different forms of governance procedures and tools, which are based on different compliance mechanisms, create a conducive environment for triggering domestic policy change.

In the 2014 NRP, Croatia announced it would accept Council recommendation and draft a Youth Guarantee Implementation Plan. It included a detailed reform agenda for the future. Passing the implementation plan was part of the ESF requirements (the so-called ex ante condition) to access funding in the 2014-2020 program. The initial intention in the Plan was, however, to upgrade the standard design and try to offer a Youth Guarantee to all youth of up to 30 years of age instead. Youth unemployment was a pressing issue in Croatia and the Youth Guarantee resonated well with the so-called "Young and Creative" package of 11 active labor market measures already implemented in 2013 through the Croatian Employment Service. The Ministry of Labor and Pension System then formed a Council for the
Implementation of the Youth Guarantee representing 17 stakeholders (including youth organizations and social partners) which worked on an Implementation Plan (MLPS 2014) for the Youth Guarantee. A Youth Guarantee coordinator was in charge of transferring knowledge from the Mutual Learning Program, as well as to steer the entire policy process.

Since the Youth Guarantee was financed through the Operational Program Efficient Human Resources agreed on only in late 2014, Croatia could not capitalize on EU funding for that entire year. A total of EUR 133 million was eventually granted for the period 2014-2020. Croatia did intend to offer a measure within 4 months, but a 2015 report showed that only 27 percent ${ }^{27}$ of all potential beneficiaries actually received an activation measure within 4 months (MLPS 2015: 21). In total, Croatia seems to have benefited from positive financial incentives from Brussels as it would not have been able to finance the measure solely through national budget lines. From time to time, termination of youth workplace training was on the table as sources ran out: "Austria, for instance, secures the money from the national budget and then just recertifies it back

27 The main reason for the poor performance is the small capacity of the Croatian Employment Service to process all applications in a timely manner, reflecting unpreparedness to live up to the high bars that were set. This risk was identified as a potential obstacle to full implementation by the Commission even before implementation started (EC 2014), and the 2016 Country Report reiterates the challenges Croatia faces in terms of under-capacitated public employment services which delay a successful rollout of the Youth Guarantee scheme. This policy fiasco is somehow mitigated by the fact that the government opened up the Youth Guarantee to the 25-30 age group as well, therefore increasing the ambition of the scheme. Nevertheless, the early intervention aspect of the Youth Guarantee has still not been fully in place since 2014 . 
Table 3. Employment-related country-specific recommendations for Croatia (20142016)

\begin{tabular}{|c|c|c|c|c|}
\hline Year & No. & Topics & $\begin{array}{l}\text { Interconne- } \\
\text { ctions }\end{array}$ & Progress \\
\hline 2014 & $3 / 8$ & $\begin{array}{l}\text { Labor market } \\
\text { participation, active labor } \\
\text { market policies, wage- } \\
\text { setting mechanisms, labor } \\
\text { market segmentation, } \\
\text { education and training, } \\
\text { pensions (retirement), tax } \\
\text { and benefit system }\end{array}$ & $\begin{array}{l}\text { Macroecono- } \\
\text { mic imbalance } \\
\text { procedure }\end{array}$ & $\begin{array}{l}\text { Some: wage setting, tax and } \\
\text { benefit system, active LMPs, } \\
\text { undeclared work, education }\end{array}$ \\
\hline 2015 & $2 / 6$ & $\begin{array}{l}\text { Labor market, labor } \\
\text { taxation, wage-setting, } \\
\text { education and skills, } \\
\text { pensions (retirement) }\end{array}$ & $\begin{array}{l}\text { Macroecono- } \\
\text { mic imbalance } \\
\text { procedure }\end{array}$ & $\begin{array}{l}\text { Limited: early retirement, } \\
\text { wage-setting, take up of } \\
\text { paid employment, social } \\
\text { benefit consolidation }\end{array}$ \\
\hline 2016 & $2 / 5$ & $\begin{array}{l}\text { Long-term sustainability } \\
\text { of pensions, Incentives to } \\
\text { work, job creation, labor } \\
\text { market participation, wage } \\
\text { and wage-setting, skills } \\
\text { and lifelong learning }\end{array}$ & $\begin{array}{l}\text { Macroecono- } \\
\text { mic imbalance } \\
\text { procedure }\end{array}$ & $\begin{array}{l}\text { No progress: Streamlining } \\
\text { pension provisions, social } \\
\text { protection system }\end{array}$ \\
\hline
\end{tabular}

Sources: For categorizations see:

http://ec.europa.eu/europe2020/pdf/csr2014/overview_recommendations_2014_by_member_state_en.pdf http://ec.europa.eu/europe2020/pdf/csr2015/csr2015-overview-table_en.pdf http://ec.europa.eu/europe2020/pdf/csr2016/csr2016-overview-table_en.pdf.

For the final CSRs see: Council $(2014,2015,2016)$; for progress evaluation see: Country Report (2015, 2016, 2017).

from the ESF. In Croatia, instead, we see measures being terminated, we run out of money...that's the problem". ${ }^{28}$

As regards the focus on the inactive NEETs, Croatia did not have specific activities targeting the inactive NEET group before the Youth Guarantee. Interviewees agree that the European Semester put the issue on the national policy agenda. ${ }^{29}$ Although the rate of NEETs is much higher in Croatia compared to the EU average (22.3 percent

28 Interviewee A3.

29 Interviewees A1 and A2. vs. 15.9 percent for 2013), the Ministry of Labor and Pension System consciously under-prioritized this group because it believed the situation was not as critical as in other countries. Namely, a high proportion of those youth consisted of tertiary education drop-outs. ${ }^{30}$

Nevertheless, the feeling among the people in charge of the Croatian Youth Guarantee was that the Commission put additional pressure on the authorities to align the national priorities to EU's focus on the inactive (NEETs).

\footnotetext{
${ }^{30}$ Interviewee A2.
} 
Demanding reporting obligations reflected this administrative pressure on the Croatian services, eventually sparking an inter-ministerial initiative to coordinate information on the entry and exit of young people in the education, labor market and social system in order to develop a tracking and monitoring system and better target policies relevant to this group. Two officials from the Ministry of Labor and Pension System said to that: "This is something the Commission pressured us to do (A2) ... Because they constantly haunt you to have measures towards inactive (A1) ... But if you realize it is useful and feasible what the Commission is proposing, then you'll do your best to implement it (A2)". ${ }^{31}$ It would seem that the perception of administrative pressure derives from frequent reporting and monitoring activities in the European Semester. The Commission would take note of domestic initiatives discussed in EMCO and frequently check on the "state of play" with national counterparts, request questionnaires to be filled, make visits during fact-finding missions and generally make frequent inquiries. ${ }^{32}$ The likely reason for the high impact can be identified in the low familiarity with the European Semester practices and the fact that the ministry staff had yet to learn how to play the Brussels game. As one interviewee put it: "Only now we actually start learning how to communicate with the Commission and how to influence what part of their ideas we can accept or not". ${ }^{33}$ The EU accession process memory of the compliance mode and obedient execution still seems to be ingrained in the public administration. ${ }^{34}$

Even during the accession negotiations it was noted that Croatia's employ-

\footnotetext{
31 Interviewees $\mathrm{A} 1$ and $\mathrm{A} 2$.

32 Interviewee A1.

33 Interviewee A2.

34 Interviewee B1.
}

ment policies were not designed based on evidence and policy evaluation. If one looks at ALPMs, it is only in the last few years that systematic evaluations of the effectiveness of ALMPs have been conducted in Croatia, owing to EU funding (for an overview, see: Bejakovic 2016; for specific evaluation results consult: Matkovic et al. 2012; and CES 2016). Hence, it comes as no surprise that continuous monitoring and evaluation of the Youth Guarantee is a potential bottleneck in the Croatian case. An EMCO member recalls how the Commission would put pressure on Croatia in the thematic reviews, constantly asking questions: "Where are your evaluations?"35 Some progress is, nonetheless, visible. With the 2014 CSR on building the capacity of the Public Employment Service, the management of the Croatian Public Employment Service used the recommendation as a strategic lever to convince decision-makers about the necessity to act: "A Slovenian colleague once thought me - Use the European Semester for things you otherwise would not be able to do because of your politicians. And we did, when we saw the CSR on capacities of the Employment Service". For instance, the Ministry of Labor and Pension System published a progress report in 2015 in which it monitored to what extent the proposed reform measures were implemented. Besides those institutional frameworks for monitoring active labor market policies, an advanced labor market monitoring system is currently being set up which will aggregate life-cycle data on education, employment and unemployment entries and exits of individuals with the purpose of monitoring employment and salary developments across sectors and occupations in real time (GRC 2015; MLPS 2015). This measure intends to address objections from the Commission 2015 Country Report as 35 Interviewee B2. 
regards the high mismatch between labor market needs and educational outcomes. Again, interviews confirm that this policy innovation was also fueled by the Youth Guarantee: "First we only saw the recommendation suggesting activation within 4 months, but eventually it produced many more structural changes". ${ }^{36}$ If one remembers that the Youth Guarantee Implementation Plan had to be passed to qualify for ESF funding, it becomes evident that this formal requirement sparked further monitoring and reporting activities and eventually led to structural changes.

It can be concluded that the Croatian Youth Guarantee scheme built heavily on pre-existing policy initiatives for the youth (mostly the workplace training without commencing work) and utilized the momentum at the EU level to further promote a very one-sided Youth Guarantee model that neglected the employment and education aspect of the Guarantee, but relied heavily on traineeship schemes. A high-profile official from the Public Employment Service reflected: "The Youth Guarantee is a good instrument, but all the money was thrown into activation measures". ${ }^{37}$ The Milanovic Government repeatedly took credit for implementing the Youth Guarantee, framing it as a truly Croatian initiative without any reference to the EU level, both in promotional material and ahead of the 2015 general elections. ${ }^{38}$ It publicly promoted the initiative as their brainchild. Although progress in terms of creating more targeted measures for unemployed youth following the adoption of the Youth Guarantee cannot be denied, it is more interesting to note the soft administrative pressure

36 Interviewee A2.

37 Interviewee B2.

38 In the party manifesto, however, they do refer to the Youth Guarantee as a "EU project" (SDP 2015: 28). that was applied by the Commission to reach out to inactive NEETs and monitor labor market developments. In general, officials from the Ministry of Labor and Pension System had the feeling that the Commission tried to enforce the Council recommendation in a directive-like manner: "We were told it's a recommendation, that you can get money for it, that it's country-specific... but in the end, we implement it as if it a directive, for God sake. It really feels that way". ${ }^{39}$ Demanding reporting obligations eventually "forced" the authorities to put more emphasis on the inactive NEETs and to upgrade monitoring tools. In general, however, the Croatian Youth Guarantee strategically used EU-proposed policy measures to bolster a pre-defined reform agenda (primarily in relation to the work-place training scheme). EU moneys were heavily mobilized and contributed to ongoing incremental changes in the policy design and institutional framework for youth employment policies in Croatia. The findings largely support expectations on the effects of monitoring and reporting obligations on policy change. Empirical evidence, particularly on the crucially supportive role that ESF money and ex ante conditions had on the Youth Guarantee recommendation, confirms that external incentives were a major facilitator of policy change.

\section{Regulation of (early) retirement}

Croatia is no exception when it comes to the old-continent syndrome. The situation in Croatia is, however, particularly severe compared to other EU Member States. Croatia records some of the worst results on a broad scale of indicators: duration of working life, proportion of early retirements, activity rate of older people, proportion of disability pensions, employee-per-retiree ratio,

${ }^{39}$ Interviewee A2. 
just to mention a few. To this end, the European Commission has persistently been proposing measures to discourage and penalize more stringently early retirement, to improve active ageing, to increase the statutory retirement age, to streamline criteria for special pensions and disability pensions and to improve the fiscal sustainability of the pension system. The overview of CSRs in Table 3 has shown that this hot topic area figures highly on the list of employment recommendations even after the accession to the EU. Special emphasis on the side of the EU has been placed on the regulation of statutory retirement age and the gender mismatch (disharmony).

Similar to other CSRs, the one that stresses the need to harmonize the retirement age for male and female workers has been linked to the Macroeconomic Imbalance Procedure. Other governance mechanisms and instruments on the EU level that focus the attention on how to increase retirement age include the 2010 Council conclusions on active ageing, the annual Active ageing report coordinated by the Commission - hence, mostly non-intrusive, soft tools. Still, empirical evidence suggests that the Commission's involvement resembles the hardening of soft procedures, strikingly so within the EMCO settings. In the assessment of the Croatian 2014 National Reform Program, the Commission battered the retirement age harmonization process as not "sufficiently ambitious" (EC 2014a: 15). Although the working document does blame Croatia for not taking other action to discourage early retirement (apart from stricter disability pension test now being applied), raising the statutory retirement age from 65 to 67 and equalizing the retirement age for both genders as soon as possible was central in the discussions in the Employment Committee as well. Interviewee data suggests that the European Commission repeatedly insisted that the harmonization of statutory retirement age be accelerated, despite the fact that the Social Democratic government passed a new Pension Insurance Law in 2013 which stipulated that a gradual phasing in of a harmonized male and female statutory retirement age would be completed by 2038. At that point, both genders would have to retire at a later age than before - at 67 years of age. Participants in the EMCO meetings report that the discussion on this particular CSR was nothing but consensus-building and open for negotiations: "The Commission was very aggressive towards Croatia, which prompted Member States' reactions. The Commission's argumentation was not strong, their positions was rather to point to things that Croatia did not fulfill, a position that was very domineering, and which lead to antagonisms, that is, greater support and sympathy for the Croatian position". ${ }^{40}$ This confirms to a certain degree previous findings that the Commission is not giving in to the hard sell by Member States and perseveres in its strives.

Surprisingly, the Milanovic Government decided not to follow the usual informal practice of paying at least lip service to the official CSRs when the recommendations go the opposite direction from the preferred policy bent. Instead, the 2015 NRP bluntly refused to follow the recommendation to increase the statutory retirement age to 67 earlier and to harmonize statutory retirement age for men and women faster. The former Minister of Labor and Pension System publicly rejected any thought about listening to the advice from Brussels. Interestingly, the CSRs that were issued after the NRP was submitted omitted any reference to speeding up, but focused on abandoning special pension schemes

40 Interviewee $\mathrm{B} 1$. 
and gaps between statutory and early retirement age provisions. A former government member recalls that this was a huge point of confrontation between the European Commission and Croatia. ${ }^{41}$ However, the Croatian government managed to convince the Commission that a faster equalization would be detrimental to the Croatian workers. The argument was that the life expectancy of Croatian workers was below the EU average, thus any action to accelerate the harmonization of the retirement age would be catastrophic. ${ }^{42}$ This explains why the Commission stopped insisting on this policy measure in the following iteration. However, besides those strong policy convictions that guided the Milanovic Government to confront the Commission and the fact that it was a sensitive policy issue, one must consider the political context of that moment. The Milanovic coalition government had a thin majority in the parliament, and one of the coalition partners was the Croatian Party of Pensioners, holding 4 mandates - enough to act as a game changer or veto player. It was believed that succumbing to the Commission's pressure on that item could have splintered the coalition's voting base, and eventually lead to intra-coalition tensions. ${ }^{43}$ In a nutshell, three conditions inhibited any progress on that issue: the fact that the topic was highly sensitive, that the government's argument was strong and the coalition make-up.

In 2016, the issue was back on the table after a seemingly dramatic joint press conference ${ }^{44}$ by Commissioner and vice-president of the Commission Valdis Dombrovskis and the technocratic Prime Minister Tihomir Orešković amidst the publication of the 2016

\footnotetext{
41 Interviewee A3.

42 Interviewee A3.

43 Interviewee B1.

${ }^{44}$ See: Večernji.hr (2016).
}

Country Report. Commenting on the assessment of Croatia's progress on CSRs, Orešković hinted that the European Commission could initiate an Excessive Imbalances Procedure, an enhanced monitoring mechanism within the framework of the Macroeconomic Imbalance Procedure in which the Commission could propose corrective measures. Commission staff confirmed ${ }^{45}$ that at that point the Commission was most determinate in updating Croatia's status in the MIP to the worse. The term "corrective measures" soon echoed in the public, evoking thoughts on sanctions (HRT 2016). Although the procedure foresees no penalties for non-Eurozone member states, media outlets and economic experts alike sent out threatening, at times contradictory messages. In reality, Croatia could only risk suspension of funds if it did not seriously engage in potential corrective actions. Vice-president Dombrovskis practically engaged in a naming-and-shaming exercise that was heavily followed by the media. Still, the right-wing government reacted fast to the threat of sanctions and decided to revive the retirement age issue in the 2016 National Reform Program. The government pledged to accelerate the equalization and oblige both male and female workers to work until the age 67, starting with the year 2027. The Plenković Government stayed committed to the same cause; however, no legislative changes had yet been initiated at the time of writing this paper.

\section{Conclusion}

This paper drew on expert interviews to study the impact of European Semester policy coordination on Croatian employment policies. The results of the study are largely in line with similar research (Louvaris Fasois 2016) in that the European Semester, through

45 Interviewee E1. 
its standard reporting procedures and intensified monitoring activities, can guide Member States to focus on specific employment goals. Much of the OMC literature findings resonate well with the empirical evidence in this paper. The Croatian government made ideational use of European initiatives (Youth Guarantee, active ageing) to promote pre-existing reform agendas, stakeholders used the European Semester recommendations as levers to promote their priorities (Croatian Employment Service's evaluation capacities) and internal government procedures were adjusted to the coordination requirements of the European Semester. Most importantly, the European Commission was able to exert adaptational pressure on the Youth Guarantee implementation through intensified monitoring within the European Semester. Interview data indicated that civil servants were caught by surprise and did not know how to resist the pressure to comply, even though the Commission had no hard tools to enforce their requests. This would indicate the importance of multi-level socialization in EU's socio-economic governance framework. Being new to the procedure, the domestic level was at first very receptive to EU-level impulses on the YG. The more accustomed the public administration becomes to bilateral interactions on soft policy matters, the more likely it is that, sooner or later, they will develop strategies on how to prevent unwanted requests, and resist existing ones. The added value of this study is that it managed to avoid a positive selection of cases that confirm EU influence. The example of retirement policy clearly highlights the limits of European Semester penetration, and both scholars and policy-makers should account for factors that might hinder policy transfers. Finally, the intensification of EU activity in soft law areas such as employment policy is not without risks.
Scholarly research has already identified the danger of over-bureaucratizing the European Semester (Maricut and $\mathrm{Pu}$ etter 2018). Besides, some governments from Central and Eastern European countries, although welcoming the European Semester, have already expressed concerns about the complex system. Reflecting on the 5 years of the Europe 2020 strategy (mid-term review), they describe the Semester as "administratively demanding"46, criticize the tight schedules ${ }^{47}$ which leave little room for genuine dialogue and policy reflection, expose the oversupply of sometimes overlapping documents, initiatives and reports, ${ }^{48}$ and emphasize that strategies such as the Agenda for new skills and jobs "have not proved to be a catalyst of strategically oriented and coherent initiatives with clear priorities". ${ }^{49}$ Hence the attention of the EU, especially in these challenging times for the European project, should shift to legitimacy-building of the European Semester so that the risks of backlashes from the capitals are avoided. Some movement in the right direction can be observed, such as in deploying the European Semester Officers to capitals or in providing technical support for structural reforms so as to increase the domestic ownership of the European Semester and reform processes. Future research should give an answer to the question to what extent the European Semester has the capacity to engage in deeper dialogue with national capitals, encourage stakeholder involvement and build acceptance of its reform agenda.

46 Ministry of Finance of the Slovak Republic (2014).

47 The Government of the Czech Republic (2014); Ministry of Finance of the Republic of Bulgaria (2014).

${ }^{48}$ Ministry of Economics of the Republic of Latvia (2014).

49 The Government of the Czech Republic (2014). 


\section{References}

Armstrong, Kenneth. 2012. EU Social Policy and the Governance Architecture of Europe 2020. Transfer. (18) 3: 285-300.

Barcevičius, Egidijus, Weishaupt, J. Timo, Zeitlin, Jonathan. 2014. Assessing the Open Method of Coordination. Institutional Design and National Influence of EU Social Policy Coordination. Basingstoke: Palgrave Macmillan.

Bejaković, Predrag. 2016. Razvoj mjera aktivne politike zapošljavanja u Hrvatskoj i njihova evaluacija. Revija $z a$ socijalnu politiku. (23) 2: 285-294.

Bejaković, Predrag, Vehovec, Maja, Mrnjavac, Željko. 2015. The Implementation and problems of Youth Guarantee Model in Croatia. Euromemo Group Working paper.

Bekker, Sonja. 2013. The EU's stricter economic governance: a step towards more binding coordination of social policies? WZB Discussion Paper SP IV 2013-501.

Bekker, Sonja. 2015. European socioeconomic governance in action: coordinating social policies in the third European Semester. European Social Observatory Paper Series. No. 19, January 2015.

Bekker, Sonja. 2016. Is there flexibility in the European Semester process? Exploring interactions between the EU and member states within post-crisis socio-economic governance. Report No. 1, January 2016. Stockholm: Swedish Institute for European Policy Studies (SIEPS).

Bekker, Sonja, Klosse, Saskia. 2014. The Changing Legal Context of Employment Policy Coordination. How do Social Policy Issues Fare after the Crisis? European Labour Law Journal. (5) 1: 7-17.
Borrás, Susana, Radaelli, M. Claudio. 2011. The politics of governance architectures: creation, change and effects of the EU Lisbon Strategy. Journal of European Public Policy. (18) 4: 463-484.

Börzel, Tanja, Risse, T. 2000. When Europe Hits Home: Europeanization and Domestic Change. European Integration Online Papers (EIoP) 4, No. 15.

Büchs, Milena. 2007. New Governance in European Social Policy: The Open Method of Coordination. Basingstoke: Palgrave Macmillan.

Brkić, Mislav. 2015. Labour market duality and the impact of prolonged recession on employment in Croatia. Croatian Economic Survey. (17) 1: 5-45.

Cacciatore, Federica, Natalini, Alessandro, Wagemann, Claudius. 2015. Clustered Europeanization and national reform programmes: a qualitative comparative analysis. Journal of European Public Policy. (22) 8: 11861211.

Chabanet, Didier. 2014. Between Youth Policy and Employment Policy: The Rise, Limits and Ambiguities of a Corporatist System of Youth Representation within the EU. Journal of Common Market Studies. (52) 3: 479-794.

Coman, Ramona, Ponjaert, Frederik. 2016. From one Semester to the next: towards the hybridization of new modes of governance in EU policy. Cahiers du CEVIPOL Brussels Working Papers, 5/2016.

Copeland, Paul, Haar, Beryl. 2015. The Open Methods of Coordination as Amplifier for EU Soft Law: The Case of EU Youth Policy. Acta Juridica Hungarica. (56) 1: 14-29.

Council of the European Union. 2010. Council conclusions on active ageing. 
Luxembourg: EPSCO Council meeting.

Council of the European Union. 2013. Draft Council conclusions on Croatia. Brussels: Economic and Financial Committee.

Croatian Employment Service. 2016. External Evaluation of Active Labour-Market Policy Measures 20102013. Summary Evaluation Report. Zagreb: Croatian Employment Service.

De la Porte, Caroline, Heins, Elke. 2015. A New Era of European Integration? Governance of Labour Market and Social Policy since the Sovereign Debt Crisis. Comparative European Politics. (13) 1: 8-28.

De la Porte, Caroline, Pochet, Philippe. 2012. Why and how (still) study the Open Method of Co-ordination (OMC). Journal of European Social Policy. (22) 3: 336-349.

Deroose, Servaas, Griesse, Jörn. 2014. Implementing economic reforms are EU Member States responding to European Semester recommendations? ECOFIN Economic Briefs. Brussels, Issue 37, October 2014.

Dunlop, A. Claire, Radaelli, M. Claudio. 2016. Policy learning in the Eurozone crisis: modes, power and functionality. Policy Sci. 49: 107-124.

Eihmanis, Edgars. 2017. Cherry-picking external constraints: Latvia and EU economic governance, 2008-2014. Journal of European Public Policy. (25) 2: 231-249.

European Commission. 2013. Assessment of the 2013 economic programme for Croatia. Commission Staff Working Document (2013) 361 final. Brussels: European Commission.

European Commission. 2014. Assessment of the 2014 national reform programme and convergence programme for Croatia. Commission Staff Work- ing Document, COM (2014) 412 final. Brussels: European Commission.

European Commission. 2014. Macroeconomic imbalances Croatia 2014. Occasional Paper 179. Brussels: European Commission.

European Commission. 2015. Country Report Croatia 2015 including an In-Depth Review on the prevention and correction of macroeconomic imbalances. Commission Staff Working Document, COM (2015) 85 final. Brussels: European Commission.

European Commission. 2016. Country Report Croatia 2016 including an In-Depth Review on the prevention and correction of macroeconomic imbalances. Commission Staff Working Document, SWD (2016) 80 final. Brussels: European Commission.

European Commission. 2017. Country Report Croatia 2017 including an In-Depth Review on the prevention and correction of macroeconomic imbalances. Commission Staff Working Document, SWD (2017) 76 final. Brussels: European Commission.

Gomez Urquijo, Laura. 2017. The Europeanisation of policy to address poverty under the new economic governance: The contribution of the European Semester. Journal of Poverty and Social Justice. (25) 1: 49-64.

Graziano, Paolo, Jacquot, Sophie, Palier, Bruno. (eds.). 2011. The EU and the Domestic Politics of Welfare State Reforms. Europa, Europa. Basingstoke: Palgrave Macmillan.

Hall, A. Peter. 1993. Policy Paradigms, Social Learning, and the State. The Case of Economic Policymaking in Britain. Comparative Politics. (25) 3: 275-296.

Hallerberg, Mark, Marzinotto, Benedicta, Wolff, B. Guntram. 2012. On the effectiveness and legitimacy of $E U$ 
economic policies. Bruegel Policy Brief. Brussels: Bruegel Institute.

Heidenreich, Martin, Zeitlin, Jonathan. 2009. Changing European Employment and Welfare Regimes: The influence of the open method of coordination on national reforms. London and New York: Routledge.

Heidenreich, Martin. 2009. The Open Method of Coordination. A pathway to the gradual transformation of national employment and welfare regimes? In: Heidenreich, Martin, Zeitlin, Jonathan. 2009. Changing European Employment and Welfare Regimes: The influence of the open method of coordination on national reforms. London and New York: Routledge.

Hrvatska radiotelevizija (HRT). 2016. Dnevnik, 26 February 2016. Retrieved from: http://www.hrt.hr/enz/ dnevnik/324041/. Accessed on 21 January 2018.

Louvaris Fasois, Christos. 2016. The effects of the European Semester on Belgium's pension reforms and tax-shift away from labour: an empirical study. Paper presented at the European Consortium for Political Research Standing Group/External SGEU Conference in Trento, Italy, 15-18 June, 2016.

Maggetti, Martino, Gilardi, Fabrizio. 2014. Network Governance and the Domestic Adoption of Soft Rules. Journal of European Public Policy. (21) 9: 1293-1310.

Maricut, Adina, Puetter, Uwe. 2018. Deciding on the European Semester: The European Council, the Council and the enduring asymmetry between economic and social policy issues. Journal of European Public Policy. (25) 2: 193-211.

Martínez-Yáñez, Nora. 2016. Rethinking the Role of Employment and Social Policy Coordination Competences in a Deeper Economic Union. European Labour Law Journal. (7) 4: 523-547.

Matković, Teo, Babić, Zdenko, Vuga, Annamaria 2012. Evaluacija mjera aktivne politike zapošljavanja 2009. i 2010. godine u Republici Hrvatskoj. Revija za socijalnu politiku. (19) 3: 303-336.

Ministry of Labour and Pension System. 2014. Implementation plan for the Youth Guarantee. Zagreb: Ministry of Labour and Pension System.

Ministry of Labour and Pension System. 2015. Report on the implementation of the Implementation plan for the Youth Guarantee in 2014. Zagreb: Ministry of Labour and Pension System.

Ministry of Economics of the Republic of Latvia. 2014. Latvia's Non-Paper and Contribution to the Public Consultation on the Europe 2020 Strategy. Riga.

Ministry of Finance of the Republic of Bulgaria. 2014. Position of the Republic of Bulgaria on the Midterm review of the "Europe 2020" strategy. Sofia.

Ministry of Finance of the Slovak Republic. 2014. Position of the Slovak Republic on the Midterm review of the "Europe 2020" strategy. Bratislava.

Moumoutzis, Kyriakos, Zartaloudis, Sotirios. 2016. Europeanization Mechanisms and Process Tracing: A Template for Empirical Research. Journal of Common Market Studies. (54) 2: 337-352.

Puetter, Uwe. 2012. Europe's deliberative intergovernmentalism: the role of the Council and European Council in EU economic governance. Journal of European Public Policy. (19) 2: 161178.

Puetter, Uwe. 2014. The European Council and the Council: New intergovernmentalism and institutional change. Oxford: Oxford University Press. 
Rohlfing, Ingo. 2016. Process tracing is possible with most-likely and least-likely cases. https://ingorohlfing. wordpress.com/2016/04/30/processtracing-is-possible-with-most-likely-and-least-likely-cases/ (Accessed: January 3, 2018).

Sabatier, Paul A. 2007. Theories of the Policy Process. Boulder: Westview Press.

Savage, James D., Verdun, Amy. 2016. Strengthening the European Commission's budgetary and economic surveillance capacity since Greece and the euro area crisis: a study of five Directorates-General. Journal of European Public Policy. (23) 1: 101-118.

Social Democratic Party of Croatia. 2015. Hrvatska raste: nema povratka na staro. Program koalicije. Retrieved from: http://www.vecernji.hr/media/ files/2015-40/program_koalicije_hrvatska_raste.pdf (Accessed: February 15, 2017).

The Council of the European Union. 2003. Council Decision of 22 July 2003 on guidelines for the employment policies of the Member States. Brussels: The Council of the European Union.

The Council of the European Union. 2014a. Council Recommendation of 8 July 2014 on the National Reform Programme 2014 of Croatia and delivering a Council opinion on the Convergence Programme of Croatia. 2014 (2014/C 24/10). Brussels: The Council of the European Union.

The Council of the European Union. 2014b. Council Recommendation of 20 April 2013 on establishing a Youth Guarantee. 2013/C 120/01. Brussels: The Council of the European Union.

The Council of the European Union. 2015. Council Recommendation on 14 July 2015 on the 2015 National Reform Programme of Croatia and delivering a Council opinion on the 2015 Conver- gence Programme of Croatia (2015/C 272/15). Brussels: The Council of the European Union.

The Council of the European Union. 2016. Council Recommendation on 12 July 2016 on the 2016 National Reform Programme of Croatia and delivering a Council opinion on the 2016 Convergence Programme of Croatia (2016/C 299/23). Brussels: The Council of the European Union.

The Government of the Republic of Croatia. 2013. 2013 Economic Programme of Croatia. Zagreb: The Government of the Republic of Croatia.

The Government of the Republic of Croatia. 2014. Guidelines for the development and implementation of active labour market policies in the Republic of Croatia for the period 2015-2017. Zagreb: The Government of the Republic of Croatia.

The Government of the Republic of Croatia. 2014. National Reform Programme. Zagreb: The Government of the Republic of Croatia.

The Government of the Republic of Croatia. 2015. National Reform Programme 2015. Zagreb: The Government of the Republic of Croatia.

The Government of the Republic of Croatia. 2016. National Reform Programme 2016. Zagreb: The Government of the Republic of Croatia.

The Government of the Republic of Croatia and the European Commission. 2014. Operational Programme under the 'Investment for Growth and Jobs' Goal. ESF Operational Programme Efficient Human Resources 2014-2020. Zagreb and Brussels: The Government of the Republic of Croatia and the European Commission.

The Government of the Czech Republic. 2014. Public Consultation on the Europe 2020 Strategy. Answers to the Questionnaire. Prague. 
Van Gerven, Minna, Vanhercke, Bart, Gürocak, Susanna. 2014. Policy Learning, Aid Conditionality or Domestic Politics? The Europeanization of Dutch and Spanish Activation Policies Through the European Social Fund. Journal of European Public Policy. (21) 4: 509-527.

Večernji.hr. 2016. Orešković: Izgubili smo 4 godine, prijeti nam postupak korektivnih mjera. Retrieved from: https://www.vecernji.hr/vijesti/tihomir-oreskovic-situacija-je-vrlo-ozbiljna-ova-vlada-nece-pricati-nego-cemo-raditi-1063566 (Accessed: May, 10, 2017).

Verdun, Amy. 2015. A historical institutionalist explanation of the EU's responses to the euro area financial crisis. Journal of European Public Policy. (22) 2: 219-237.

Verdun, Amy, Zeitlin, Jonathan. 2018. Introduction: the European Semester as a new architecture of EU socioeconomic governance in theory and practice. Journal of European Public Policy. (25) 2: 137-148.

Vukšić, Goran. 2014. Employment and employment conditions in the current economic crisis in Croatia. Financial Theory and Practice. (38) 2: 103-138.

Woll, Cornelia, Jacquot, Sophie. 2010. Using Europe: Strategic action in multi-level politics. Comparative European Politics. (8) 1: 110-126.
Zartaloudis, Sotirios. 2013. Wielding Soft Power in a World of Neglect: The Europeanization of Greek and Portuguese Public Employment Services. Journal of Common Market Studies. (51) 6: 1178-1195.

Zeitlin, Jonathan. 2015. Introduction. In: Zeitlin, J. (ed.). 2015. Extending Experimentalist Governance? The European Union and Transnational Regulation. Oxford: Oxford University Press, pp 1-19.

Zeitlin, Jonathan. 2016. EU experimentalist governance in times of crisis. West European Politics. (39) 5: 10731094.

Zeitlin, Jonathan, Vanhercke, Bart. 2014. Socializing the European Semester? Economic Governance and Social Policy Coordination in Europe 2020. Stockholm: Swedish Institute for European Policy Studies (SIEPS), 7.

Zeitlin, Jonathan, Pochet, Philippe. (eds.). 2005. The Open Method of Co-ordination in Action. The European Employment and Social Inclusion Strategies. Bruxelles: Verlag Peter Lang.

Zuleeg, Fabian. 2015. Economic policy coordination in the Euro area under the European Semester. In-depth analysis requested by the Economic and Monetary Affairs Committee of the European Parliament. Brussels: European Parliament. 


\section{Utjecaj Europskog semestra na politike zapošljavanja u Hrvatskoj, 2013-2016.}

Sažetak Članak analizira učinke Europskog semestra, okvira EU-a za socijalno-ekonomsku koordinaciju, na promjenu politike zapošljavanja u Hrvatskoj. Slučaj Hrvatske treba ilustrirati kako, pod kojim uvjetima i u kojoj mjeri arhitektura Europskog semestra utječe na politike zapošljavanja u Hrvatskoj. U žarištu su analize dvije stavke javnih politika: Garancija za mlade i dob za umirovljenje. Nalazi vezani za Garanciju za mlade podržavaju očekivanje prema kojemu pojačani nadzor i obveze izvještavanja pridonose promjeni nacionalnih javnih politika. Koristeći intervjue kao izvore podataka, auto pronalazi dva ključna elementa utjecaja: administrativni pritisak i slabu upoznatost s načinom rada Europske komisije u sklopu Europskog semestra. Istodobno, Hrvatska je opetovano zanemarivala preporuke za usklađivanjem dobi umirovljenja za muškarce i žene. Razlozi slaba utjecaja Europskog semestra na tom području mogu se pronaći u ograničavajućem efektu sastava koalicijske vlade, krutosti javne politike, suprotstavljenih uvjerenja i vrlo neizvjesne političke situacije. Ti su uvjeti bili čimbenici odvraćanja od promjene javnih politika, unatoč mogućim sankcijama EU-a.

Ključne riječi Europski semestar, europeizacija, politike zapošljavanja, Hrvatska, Garancija za mlade, umirovljenje 